\title{
Extended producer responsibility (EPR) and job creation in Korea
}

\author{
J. H. Kim \\ Seo-kyeong University, South Korea
}

\begin{abstract}
Extended Producer Responsibility (EPR) is a system that imposes a certain quota for the recyclable waste from products or packaging materials on the manufacturer of the products. If the quota is not complied with, a fine that is greater than the cost of implementing proper recycling shall be imposed upon the manufacturer. Since the introduction of the EPR system in 2003 in Korea, product recycling has continuously increased. The output of EPR items in 2007 increased by $11.6 \%$, while the amount of items recycled for the same year increased by $32.3 \%$, compared to the period before the EPR system was implemented. Also, it is estimated that 2,264.3 billion won (2.05 billion US \$) of economic benefits and 4,260 new jobs have been created in the 5 years (20032007) following the implementation of the EPR system. However, before starting the EPR system, several steps must be taken in advance. The first step is a general governmental role in recycling. The second step should involve citizens' role or consumers' responsibility. A volume-based garbage collection fee (VGCF) system is a kind of citizens' burden for voluntary participation in paying more for sorting of recyclable materials instead of paying more garbage collection fees. After that, the government and consumers may naturally ask producers to take responsibility for more recycling without polluting the environment. One of the important experiences in the Korean EPR is the shared responsibility concept among governments, consumers, and producers.

Keywords: extended producer responsibility, municipal solid waste management, resource-circulating society, sustainable development, venous or recycling industry, volume-based garbage collection fee system.
\end{abstract}




\section{Introduction}

For over two decades in Korea, various kinds of waste-related conflicts have been delivering new and innovative methods in urban waste management. Until now, Korean municipal solid waste (MSW) has been managed by both the challenging system, known as the Volume-based Garbage Collection Fee (VGCF) system, and OECD-suggested as the EPR system. Unlike the traditional government-oriented systems, the VGCF system, based on citizens' participation or consumers' burden, was used to its full effect starting in 1995. After successful implementation of the VGCF system, the EPR system, which is based on the producers' obligation, began in 2003. Therefore, Korean MSW management system is based mainly on three pillars of recycling responsibility: (1) traditional local governments' responsibility - overall recycling services; (2) consumers' responsibility through VGCF - voluntary sorting of recyclable materials or pay-as-you-throw; and (3) producers' responsibility through EPR voluntary agreement that imposes a certain quota on recyclable waste from products.

\section{A solution to urban waste problems: the VGCF system}

Since the early 1990s in Korea, waste problems have emerged as one of the biggest urban issues. The rapidly growing economy has led to mass production and mass consumption, which, in turn, has resulted in an increase in the amount of waste generated. Complaints and strong movements against constructing new waste treatment facilities have forced Korea to seek a different approach to tackling waste problems, rather than just focusing on the supply of waste treatment facilities. Under these circumstances, the Volume-based Garbage Collection Fee (VGCF) system was introduced. The amount of municipal solid waste generated in Seoul came to a daily average of 15,397 tons in 1994. Most waste (12,238 tons) was incinerated or landfilled, and 3,159 tons $(20.5 \%)$ were recycled. In 1995, the year in which the VGCF system started, the amount of domestic waste was reduced by $8.4 \%$, to a daily average of 14,102 tons. Only 9,965 tons were incinerated or landfilled, and 4,137 tons $(30.9 \%)$ were recycled [1]. Amount of treated waste was diminished by $18.6 \%$, and, in contrast, recycled waste increased by $31 \%$. Although this system appears to be very simple, there were several difficulties that needed to be overcome in order to implement the system.

\section{Risks and advantages of the 1997 Korean economic crisis}

The successful results from the VGCF system were tremendous in both reducing waste and increasing recyclable materials. However, the most difficult problems from the VGCF system came from the unexpected increase in recyclable materials. Paper, cans, and even iron scraps were not recycled, the price of recyclable goods dropped, and large quantities of recyclables were accumulating in the backyards of waste hauler companies. Politicians began to blame the 
limitations of the VGCF system. Thus, only two years after the VGCF system was implemented in 1995, it suffered a major crisis. Unfortunately - or fortunately - the Korean financial crisis occurred in December 1997. The value of Korean currency (won) fell from 800 won/1 USD to 1,700 won/1 USD. The price of recyclable materials at least doubled. Most accumulated recyclable goods sold out, and recyclable material markets were reopened. After Korea experienced this economic crisis, the VGCF system was firmly established. Although the 1997 Korean economic crisis was a dismal experience, it was an important lesson that helped citizens to understand the value of the VGCF system. During this period of energy crisis, positive relationships between the economic crisis and the concept of recycling wasted material had strong implications for policy.

\section{The policy performance of the VGCF system}

The VGCF system is characterized by two disparately oriented policies. The first of these involves "recyclable materials voluntarily sorted by residents, which are curbside collected at no cost by local government." The other is that a "garbage disposal bag collection fee is charged to residents by local government according to the garbage collection volume." In the case of the Seoul area, this system has successfully reduced per capita waste generation from $1.42 \mathrm{Kg} /$ day/person in 1994 to $1.13 \mathrm{Kg} /$ day/person in 2004 , while at the same time it increased the amount of recycled materials from $0.3 \mathrm{Kg}$ /day/person in 1994 to $0.62 \mathrm{Kg} /$ day /person in 2004 [2]. The summarized policy performance of the VGCF system in Seoul metropolitan area is shown in Table1. In Korea, the EPR system has been implemented on the basis of the successful VGCF system.

Table 1: $\quad$ Policy performance of the Seoul VGCF system.

\begin{tabular}{|c|c|c|c|}
\hline \multicolumn{4}{|c|}{ Before the VGCF system in Seoul } \\
\hline \multirow[t]{2}{*}{1994} & Waste generation* & \multicolumn{2}{|c|}{15,397 tons/day } \\
\hline & & $\begin{array}{l}\text { landfill } \\
\text { incinerating } \\
\text { recycling }\end{array}$ & $\begin{array}{r}\text { 12,144 tons/day } \\
94 \text { tons/day } \\
\text { 3,159 tons/day }\end{array}$ \\
\hline \multicolumn{4}{|c|}{ After the VGCF system in Seoul } \\
\hline \multirow[t]{2}{*}{1995} & Waste generation & \multicolumn{2}{|c|}{14,102 tons/day } \\
\hline & & $\begin{array}{c}\text { landfill + incinerating } \\
\text { recycling }\end{array}$ & $\begin{array}{l}9,965 \text { tons/day } \\
4,137 \text { tons/day }\end{array}$ \\
\hline \multirow[t]{2}{*}{2004} & Waste generation & \multicolumn{2}{|c|}{11,673 tons/day } \\
\hline & & $\begin{array}{l}\text { landfill } \\
\text { incinerating } \\
\text { recycling }\end{array}$ & $\begin{array}{r}4,498 \text { tons/day } \\
749 \text { tons/day } \\
6,426 \text { tons/day }\end{array}$ \\
\hline
\end{tabular}


Table 1: $\quad$ Continued.

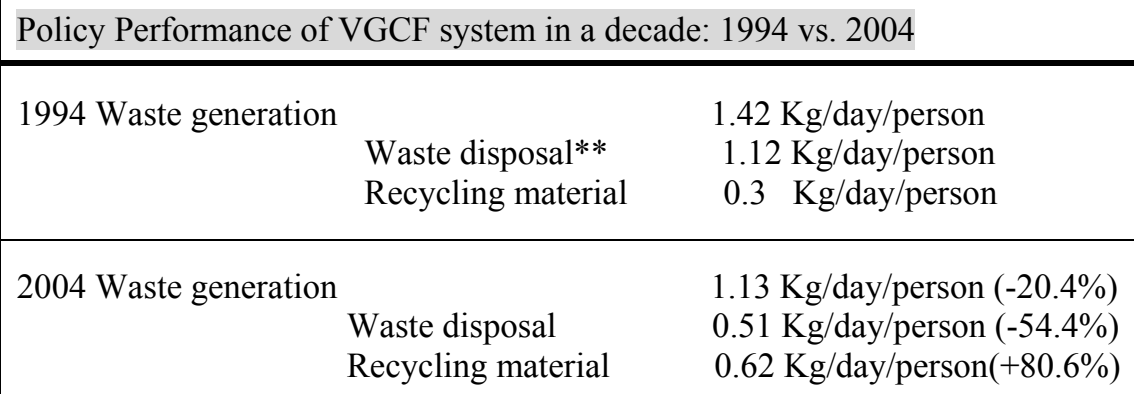

*Waste generation $=$ landfill + incinerating + recycling.

$* *$ Waste disposal $=$ landfill + incinerating.

Source: Sudokwan Landfill Site Management Corp. [3].

\section{Understanding EPR}

Extended Producer Responsibility is a system that imposes a certain quota on the recyclable waste from products or packaging materials on the manufacturer of the products. If the quota is not complied with, a fine that is greater than the cost of implementing proper recycling shall be imposed upon the manufacturer. According to OECD, the EPR system can be also understood as changing the traditional balance of responsibilities among manufacturers, consumers, and governments with regard to waste management. Although the system takes many forms, it is always characterized by the continuous involvement of producers and importers with commercial goods at the post-consumer stage. The EPR system extends the traditional environmental responsibilities that producers and importers were previously assigned to include the management of their products at the post-consumer stage [4].

\section{The Korean EPR system as shared responsibility}

The Korean EPR is basically applied to existing items under a deposit system, and new items began to be added to the EPR in 2003. As the Korean EPR system is based on both the SPR (Shared Producer Responsibility) systems and the VGCF or SCR (Shared Consumer Responsibility) systems, the consumers' responsibilities, as well as the producers' responsibilities, are cooperatively extended. As in the past, the central government and local governments take responsibility for the disposal of non-recycled wastes and overall responsibility for collection of recyclable waste and putting it into the recycling process, while the consumer eventually bears part of the recycling costs that producers pay because these are reflected in the price of products, and he or she also contributes to the easy collection of waste by separating and sorting waste products. The recycling responsibility relationships are illustrated in figure 1. 


\section{Governments' Responsibility}

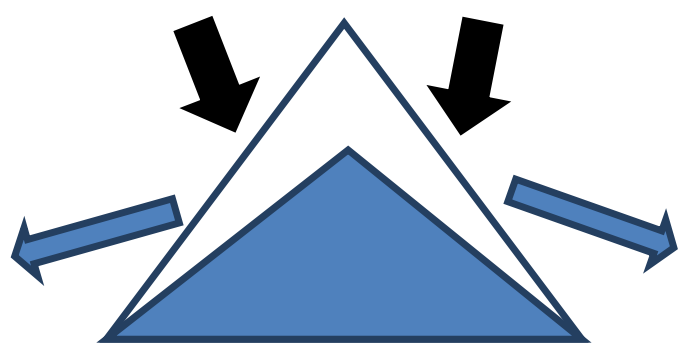

Consumers' Responsibility Producers' Responsibility

(VGCF system or SCR; (EPR system or SPR;

Shared Consumer Responsibility) Shared Producer Responsibility)

Figure 1: Recycling responsibility relationships.

\section{Implementing EPR in Korea}

In 2004, film-type packaging materials and fluorescent bulbs were added, with audio products and mobile communication devices added in 2005. Printers, copiers, and facsimile machines were added in 2006, and cosmetics were added in 2007. Finally, in 2008, manganese batteries, alkaline manganese batteries, and $\mathrm{Ni}-\mathrm{MH}$ batteries were added, so EPR is currently being applied to a total of 24 items. Also, as electric and electronic products among EPR items have become subject to the Act on the Recycling of Electrical and Electronic Equipment and Vehicles, following the enforcement of the Act since 2008, preventive management, such as restrictions on the use of hazardous materials, has been tightened (Table 2).

\section{The policy performance of EPR: job creation}

Since the introduction of the EPR system in 2003, product recycling has continuously increased. 6,069,000 tons of waste resources in total have been recycled over the 5-year period from 2003 to 2007. The output of EPR items in 2007 increased by $11.6 \%$, while the amount of items recycled for the same year increased by $32.3 \%$, compared to the period before the EPR system was implemented. Also, it is estimated that 2 trillion, 264.3 billion won of economic benefits and 4,260 new jobs were created in the 5 years following the implementation of the EPR system in 2003 (2003-2007); see also Table 3. 
Table 2: $\quad$ Items subject to EPR in Korea.

\begin{tabular}{|c|c|c|}
\hline \multicolumn{2}{|c|}{$\begin{array}{l}\text { Target goods } \\
\text { (e.g., TVs) }\end{array}$} & $\begin{array}{l}\text { TV, washing machine, air-conditioner, } \\
\text { refrigerator, PC and monitor (2003-) } \\
\text { Film-type packaging materials, fluorescent bulbs (2004-) } \\
\text { Audio equipment, mobile phone (2005-) } \\
\text { Printer, copy machine, fax machine, etc. (2006-) } \\
\text { Cosmetics (2007-) } \\
\text { Manganese batteries, alkaline manganese batteries, Ni-MH } \\
\text { batteries (2008-) }\end{array}$ \\
\hline \multirow{5}{*}{ 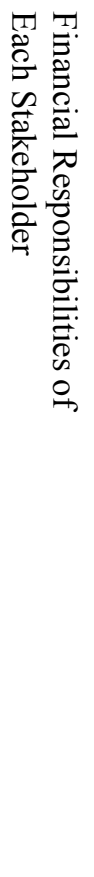 } & Consumers & $\begin{array}{l}\text { must pay collection fee to each good, except small } \\
\text { machines. For example, mobile phones are collected for } \\
\text { free at the post office. }\end{array}$ \\
\hline & Retailers & $\begin{array}{l}\text { can collect for free from consumers. } \\
\text { No strict obligation. }\end{array}$ \\
\hline & $\begin{array}{l}\text { Manufacturer } \\
\mathrm{s}\end{array}$ & $\begin{array}{l}\text { must recycle at their own expense and pay the surcharge } \\
\text { to Ministry of Environment for unperformed recycling } \\
\text { obligations. (Before the implementation of this EPR- } \\
\text { system, there was a deposit-refund system based on } \\
\text { producer responsibility. Currently, both systems co-exist.) }\end{array}$ \\
\hline & $\begin{array}{l}\text { Central } \\
\text { government }\end{array}$ & $\begin{array}{l}\text { must boost the recycling ratio to almost } 100 \% \text {, control the } \\
\text { recycling process to ensure that it is environmentally } \\
\text { sound and provide for sustainable development. }\end{array}$ \\
\hline & $\begin{array}{l}\text { Local } \\
\text { government } \\
\text { S }\end{array}$ & $\begin{array}{l}\text { must collect e-waste if residents want them to and if they } \\
\text { pay the collection fee. Then, local governments can } \\
\text { request some subsidies from the producers' organizations } \\
\text { in the EPR system. }\end{array}$ \\
\hline \multicolumn{2}{|c|}{$\begin{array}{l}\text { Regulations } \\
\text { on hazardous } \\
\text { Substances }\end{array}$} & Korean RoHS systems are implemented (2005.7-) \\
\hline \multicolumn{2}{|c|}{$\begin{array}{l}\text { Target } \\
\text { (i.e., recycling ratio) }\end{array}$} & $\begin{array}{l}\text { A recycling ratio is agreed upon between manufacturers } \\
\text { and the Ministry of Environment through the process of } \\
\text { VA (voluntary agreement). }\end{array}$ \\
\hline \multicolumn{2}{|c|}{ Other information } & $\begin{array}{l}\text { The construction of a domestic marketable e-waste system } \\
\text { for preventing e-waste "Export." }\end{array}$ \\
\hline
\end{tabular}

Source: Korean Ministry of Environment [5]. 
Table 3: $\quad$ Economic value of recycling EPR products in Korea: 2003-2007.

(Unit: Korean won, 1100 won/ 1 US \$)

\begin{tabular}{|l|l|l|l|l|}
\hline Year & $\begin{array}{l}\text { Total economic } \\
\text { benefit }(\mathrm{A}=\mathrm{B}+\mathrm{C})\end{array}$ & $\begin{array}{l}\text { Landfill } \\
\text { (incineration) } \\
\text { cost reduction (B) }\end{array}$ & $\begin{array}{l}\text { Economic value } \\
\text { of recycled } \\
\text { products }(\mathrm{C})\end{array}$ & $\begin{array}{l}\text { Generated } \\
\text { employment }\end{array}$ \\
\hline Total & $\begin{array}{l}\mathbf{2 , 2 6 4 . 3} \text { billion won } \\
\mathbf{( \$ 2 . 0 5 8} \text { billion) }\end{array}$ & $\begin{array}{l}\mathbf{1 , 2 4 9 . 7} \\
\mathbf{( \$ 1 . 1 3 6} \text { billion) }\end{array}$ & $\begin{array}{l}\mathbf{1 , 0 1 4 . 6} \\
\mathbf{( \$ 0 . 9 2 2} \text { billion) }\end{array}$ & $\mathbf{4 , 2 6 0}$ persons \\
\hline 2003 & 367.3 & 204.1 & 163.2 & 685 \\
\hline 2004 & 414.0 & 229.2 & 184.8 & 776 \\
\hline 2005 & 462.4 & 256.1 & 206.3 & 866 \\
\hline 2006 & 478.6 & 263.4 & 215.2 & 904 \\
\hline 2007 & 542.0 & 296.9 & 245.1 & 1,029 \\
\hline
\end{tabular}

Source: Korean Ministry of Environment [5].

\section{Conclusion: rethinking a venous industry}

Experiences concerning the EPR in Korea have been discussed. The EPR is a useful management system that provides a means for implementing waste minimization and recycling maximization. As most of us recognize, conventional pollution control can only regulate producers to limit the emission of pollutants at the end-of-pipe. Moreover, MSW cannot be managed at the producers' factory using negative regulation through the technology of pollution control. EPR is necessary to take several steps in advance. However, before starting the EPR system, it is necessary to take several steps in advance. The first step is usually a governmental role in MSW treatment. The second step is generally a burden or role imposed upon citizens or consumers. The VGCF is a kind of citizens' burden of voluntary participation in more recyclable materials sorting instead of paying more garbage collection fees. After that, the government and consumers can, naturally, ask producers to take on the burden of more recycling without polluting the environment. One of the important experiences in the Korean EPR is the shared concept among governments, consumers, and producers. This paper also suggests that the consumers' VGCF system and the producers' EPR system can lead to economic profits and new jobs in a venous industry, but not in an arterial industry. After squeezing virgin natural resources through fast industrialization, or arterial industry, most countries are faced with finding themselves at the edge of poverty and economic crisis. In the 21 st-century resource-circulating society, both the VGCF and the EPR systems can offer a lot of opportunities for new money and jobs in the venous or recycling industry [6].

In a resource-circulating society or a venous industry, recyclable material cannot be wasted. Attitudes are already changing worldwide. For example, an 
association of European carpet makers collects all kinds of carpets for recycling. In the past, they sorted the various carpet types by hand by using a scanning device, but now they have an automated sorting system. They expect to process 25 million $\mathrm{kg}$ of carpet each year [7]. In the case of the United States, 161 companies employ more than 9,000 people in the use of recyclables in manufacturing in Massachusetts [8]. The companies indirectly drive employment for 20,000 people involved in various support operations. Now we have to change the word 'garbage collector' to 'feedstock digger.' In the manufacturing process involved with recyclables, we can find many job opportunities. From simple feedstock diggers to company CEOs, there are a wide variety of jobs created in the process. This is the time to think together and change together as we find ways to renew the VGCF and EPR systems, such as garbage collection and recycling methods, in order to alleviate the global economic and energy crisis.

\section{References}

[1] Kim, J. H. Reducing greenhouse gases using the pay-as-you-throw (PAYT) system in Sustainable Development and Planning V. Vol. 150.WIT Press. pp. 601-602. 2011.

[2] Seoul Metropolitan Government. Seoul Statistical Year Book: 1994-2006.

[3] Sudokwan Landfill Site Management Corporation in Korea. Landfill Allowance Trading Scheme. 2004-10-001-01. 2004.

[4] OECD. Extended Producer Responsibility: A Guidance Manual For Governments. pp. 9-12. 2001.

[5] Korean Ministry of Environment. Extended Producer Responsibility. http://eng.me.go.kr/pol_rec_pol_rec_sys_responsibility (last accessed 31 January, 2012).

[6] Kim, J.H. A Resource-Circulating Society and NGO. Daeyoung Publishing Co. pp. 33-39. 2006.

[7] Williams, P.T. Waste Treatment and Disposal. Wiley Co. 2005.

[8] Hill, M.K. Understanding Environmental Pollution, Cambridge University Press. pp. 445-446. 2004. 